\title{
Neuroprotective molecular mechanisms of (-)-epigallocatechin- 3-gallate: a reflective outcome of its antioxidant, iron chelating and neuritogenic properties
}

\author{
Orly Weinreb - Tamar Amit · Silvia Mandel • \\ Moussa B. H. Youdim
}

Received: 19 July 2009/Accepted: 3 August 2009/Published online: 10 September 2009

(C) Springer-Verlag 2009

\begin{abstract}
Tea, the major source of dietary flavonoids, particularly the epicatechins, signifies the second most frequently consumed beverage worldwide, which varies its status from a simple ancient cultural drink to a nutrient component, endowed possible beneficial neuro-pharmacological actions. Accumulating evidence suggests that oxidative stress, resulting in reactive oxygen species generation, plays a pivotal role in neurodegenerative diseases, supporting the implementation of radical scavengers and metal chelating agents, such as natural tea polyphenols, for therapy. Vast epidemiology data indicate a correlation between occurrence of neurodegenerative disorders, such as Parkinson's and Alzheimer's diseases, and green tea consumption. In particular, recent literature strengthens the perception that diverse molecular signaling pathways, participating in the neuroprotective activity of the major green tea polyphenol, (-)-epigallocatechin-3-gallate (EGCG), renders this natural compound as potential agent to reduce the risk of various neurodegenerative diseases. In the current review, we discuss the studies concerning the mechanisms of action implicated in EGCG-induced neuroprotection and discuss the vision to translate these findings into a lifestyle arena.
\end{abstract}

This article belongs to a special issue on Nutrients and Brain Health.

O. Weinreb - T. Amit - S. Mandel · M. B. H. Youdim Eve Topf and USA National Parkinson Foundation Centers of Excellence for Neurodegenerative Diseases Research,

Technion-Faculty of Medicine, Haifa, Israel

O. Weinreb $(\square)$

Department of Pharmacology, Rappaport Family Research Institute, Technion-Faculty of Medicine, P.O.B. 9649, Haifa 31096, Israel

e-mail: worly@tx.technion.ac.il
Keywords (-)-Epigallocatechin-3-gallate · Neurodegenerative diseases - Radical scavenging · Iron chelation $\cdot$ Neuroprotection

$\begin{array}{ll}\text { Abbreviations } \\ \text { AD } & \text { Alzheimer's disease } \\ \text { A } \beta & \text { Amyloid beta peptide } \\ \text { ALS } & \text { Amyotrophic lateral sclerosis } \\ \text { ARE } & \text { Antioxidant response elements } \\ \text { COMT } & \text { Catechol-O-methyltransferase } \\ \text { BBB } & \text { Blood-brain barrier } \\ \text { DA } & \text { Dopamine } \\ \text { EC } & \text { (-)-Epicatechin } \\ \text { ECG } & \text { Epicatechin-3-gallate } \\ \text { EGCG } & \text { (-)-Epigallocatechin-3-gallate } \\ \text { EGC } & \text { (-)-Epigallocatechin } \\ \text { MAPK } & \text { Extracellular mitogen-activated protein } \\ & \text { kinases } \\ \text { ERK1/2 } & \text { Extracellular signal-regulated kinases } \\ \text { GAP-43 } & \text { Growth associated protein-43 } \\ \text { 6-OHDA } & \text { 6-Hydroxydopamine } \\ \text { HSP90 } & \text { Heat shock protein 90 } \\ \text { HIF-1 } & \text { Hypoxia inducible factor-1 } \\ \text { 3-HK } & \text { 3-Hydroxykynurenine } \\ \text { iNOS } & \text { Inducible nitric oxide synthase } \\ \text { MEK1 } & \text { Mitogen-activated protein kinase 1 } \\ \text { MPP } & \text { 1-Methyl-4-phenylpyridinium } \\ \text { MPTP } & N \text {-Methyl-4-phenyl-1,2,3,6- } \\ & \text { tetrahydropyridine } \\ \text { OS } & \text { Oxidation stress } \\ \text { PD } & \text { Parkinson's disease } \\ \text { PKC } & \text { Protein kinase C } \\ \text { PC12 cells } & \text { Rat pheochromocytoma cells } \\ \text { R-APO } & \text { R-apomorphine } \\ & \end{array}$


ROS Reactive oxygen species

GSH Reduced glutathione

SAPP $\alpha \quad$ Soluble amyloid precursor protein

TNF- $\alpha \quad$ Tumor necrosis-alpha

TfR Transferrin receptor

SNPC Substantia nigra pars compacta

VEGF Vascular endothelial growth factor

UPS Ubiquitin proteasome system

\section{Introduction}

Epicatechin (flavan-3-ol compound) is commonly present in green tea and abundant with phenolic hydroxyl groups on its aromatic rings, which confer its antioxidant and iron chelating activities [130]. The importance of green tea catechins in enhancing cell resistance to oxidative stress (OS) goes beyond the simple scavenging and iron chelating activities and is mostly interesting in those pathologies, where OS and iron are involved [64, 104]. Numerous studies in the last decade have shown that green tea catechins have in vitro and in vivo activities in preventing and/ or reducing the deleterious effects of oxygen-derived free radicals, associated with several chronic- and stress-related human diseases (see reviews [5, 74, 76, 100, 119, 135]). Several lines of evidence suggest that OS, resulting in reactive oxygen species (ROS) generation, either through an enzyme or metal catalyzed process, plays a pivotal role in clinical disorders, such as atherosclerosis, ischemiareperfusion injury, cancer, stroke and neurodegenerative disorders $[24,33]$. Oxidative damage to neuronal molecules and increased accumulation of iron in specific brain areas are considered major pathological aspects of Parkinson's disease (PD), Alzheimer's disease (AD) and amyotrophic lateral sclerosis (ALS) and thus, special interest has been assigned to the therapeutic feature of nutritional antioxidants and iron chelators in neurodegenerative diseases [23, 32, 74, 76, 97, 135].

A large number of epidemiological studies on PD and cognitive impairment described a moderate risk reduction in black (fermented), oolong (semi-fermented) and green (not-fermented) teas consumers, compared to non-tea drinkers $[39,84]$. The favorable properties ascribed to tea consumption are believed to rely on its bioactive flavanol class-related catechins and their derivatives, demonstrated to act as radical scavengers and exert indirect antioxidant effects through activation of transcription factors, signaling regulators and antioxidant enzymes (for reviews see: [40, $76,141])$. In line with this, particular attention has been placed to study the neuroprotective action of antioxidants, iron-chelating and anti-inflammatory agents, green tea catechins and especially, the major component of green tea, (-)-epigallocatechin-3-gallate (EGCG) [75, 82, 117]. The revelation of novel molecular targets, possibly implicated in their neuroprotective action include: calcium homeostasis [45], extracellular mitogen-activated protein kinases (MAPK) [109] and protein kinase C (PKC) signaling pathways [58, 95], regulation of antioxidant enzymes [60], antioxidant response element (ARE) [8], cell death and cell survival genes and proteins, associated with mitochondrial function, such as Bcl-2 family members [49, 59, 137, 138], amyloid precursor protein (APP) processing pathway [58, 96] and iron regulators and sensors encoding genes and proteins, such as transferrin receptor (TfR) and hypoxiainducible factor (HIF)-prolyl-hydroxylases [96, 134, 152].

This review aims to compile recent studies regarding the molecular mechanism of action, implicated in EGCGinduced neuroprotective and neuritogenic activities, which might be a reflective outcome of its effects on neuronal cell signaling pathways associated with antioxidant and iron chelating properties.

Green tea catechins: human neuronal efficacy and epidemiology studies

Green tea belongs to the Theacease family, derived from two plant varieties, Camellia sinesis and Camellia assamica [25], is the most widely consumed beverage aside from water in Japan, China and other Asian nations and presently becoming more popular in Western countries. The first scientific recognition of medicinal properties of green tea was in the sixteenth century, using extracts as therapeutic mean to cure fever, headache, stomach and articulation pain [124]. To date, green tea is generally regarded as safe by the U.S. Food and Drug Administration (FDA) [142] and has attracted attention for its health benefits, particularly with respect to its potential for preventing and treating cancer, cardiovascular diseases, inflammatory diseases, aging and neurodegenerative diseases $[42,56,139]$.

Catechins account for $25-35 \%$ of the green tea dry extract and consist of eight polyphenolic flavonoid-type compounds, namely, (+)-catechin (C), (-)-epicatechin (EC), (+)-gallocatechin (GC), (-)-epigallocatechin (EGC), $(+)$-catechingallate $(\mathrm{CG}),(-)$-epicatechin gallate (ECG), $(+)$-gallocatechin gallate (GCG) and EGCG. The most abundant catechin is EGCG, estimated that a cup of green tea ( $2.5 \mathrm{~g}$ of green tea leaves $/ 200 \mathrm{ml}$ of water) may contain $90 \mathrm{mg}$ of EGCG and thus, thought to particularly contribute to the beneficial effects attributed to green tea, such as its neuroprotective properties [68, 142].

Several reports indicated that tea polyphenols can be attained in the brain and exert neuroprotective effect simply by drinking $[60,93,94]$. The metabolism of green tea catechins has been studied in various animal models and in 
humans $[62,92]$. Orally catechin administration to humans is absorbed, metabolized and excreted within $24 \mathrm{~h}$ [38]. Study with healthy green tea consumers revealed levels of EGCG, EGC and EC in the plasma in a dose-dependent concentration, varying between 0.2 and $2 \%$ of the ingested amount, with maximal concentration $1.4-2.4 \mathrm{~h}$ after ingestion [81]. In addition, after ingestion of $1.2 \mathrm{~g}$ of green tea solids (dissolved in two cups of warm water), the plasma samples collected at $1 \mathrm{~h}$ from human volunteers contain 46-268 ng/ml [62]. The half-life for EGCG is about $5 \mathrm{~h}$ and for EGC and EC, it varies between 2.4 and $3.4 \mathrm{~h}$ [145, 146]. EGCG is the only known polyphenol present in plasma in large proportion (77-90\%) in a free form and its levels is reported to be higher in esophagus and large intestine, but lower in other organs, likely due to poor systemic absorption [5]. Preclinical studies in rat indicated that EGCG is mainly excreted through urine and bile [5]. Additionally, previous studies reported on instability of EGCG at the intestinal $\mathrm{pH}$ of 8.5 and a low bioavailability, while antioxidants (e.g. ascorbic acid and selenium) demonstrated to stabilize EGCG in the lumen and help to build up its concentration in the intestine. This suggests that poor absorption from the small intestine may play an important role in limiting EGCG bioavailability [21].

Previous study of oral green tea administration established the chemical identity of two major tea catechin metabolites, (-)-5-( $3^{\prime}, 4^{\prime}, 5^{\prime}$-trihydroxyphenyl)- $\gamma$-valerolactone and $(-)-5-\left(3^{\prime}, 4^{\prime}\right.$-dihydroxyphenyl $)-\gamma$-valerolactone, in human urine and blood. These metabolites appeared to be formed by the intestinal flora in the human colon and then absorbed [62]. In addition, previously, it was reported that EC metabolites (epicatechin glucuronide and $3^{\prime}$-O-methylated epicatechin glucuronide) formed after oral ingestion of EC by rats, had gained entry to the brain [1]. Furthermore, study with labeled EGCG demonstrated a wide distribution of radioactivity in mouse organs including brain, after oral administration and small amount of $\left[{ }^{3} \mathrm{H}\right]$ EGCG excretion in the urine after direct administration [123]. Recently, the absorption and pharmacokinetic of EGCG in various brain regions of adult and fetal rats have been demonstrated by oral and intravenous administration, indicating that EGCG is the most abundant catechin in brain tissue $[65,68]$ and may potentially penetrate through the blood-brain barrier (BBB) [12]. In vitro model of BBB demonstrated that various flavonoids and some metabolites were able to traverse the BBB and that the potential for permeation was consistent with compound lipophilicity [149].

Albeit the uncertainty on the capacity of green tea catechins to penetrate the brain, green tea was suggested to inversely correlate with the incidence of brain aging, dementia and neurodegeneration, such PD and AD.
Previous epidemiological studies have shown a reduced risk of $\mathrm{PD}$ associated with consumption of 2 cups/day or more of black tea [7]. In support, Tan et al. [126] found an inverse association between black tea and PD, based on a 12-year prospective study of over 63,000 men and women, which was due to black tea ingredients separate from its caffeine content. In a cross-sectional study, aimed at investigating an association between consumption of green tea and cognitive function in elderly Japanese subjects, it was found that higher consumption of green tea is associated with lower prevalence of cognitive impairment [55]. Despite the fact that the prevalence of PD is much lower in tea consumers, the association of green tea drinking and risk of $\mathrm{AD}$ and other neurodegenerative diseases is not well established. No case-control study has been accomplished that points to a beneficial effect associated with tea consumption in $\mathrm{AD}$, although recently $\mathrm{Ng}$ et al. [84] performed analysis of green tea intake by comparing baseline data from 2,501 participants and 1,438 cognitively intact participants from 2-year follow-up of Chinese cohort in the Singapore Longitudinal Ageing Study. Green tea was inversely associated with cognitive impairment, but not with cognitive decline, possibly due to the small number of green tea drinkers in this cohort. These findings emphasize the importance of well-designed controlled studies to assess a risk reduction of $\mathrm{PD}$ and $\mathrm{AD}$ in consumers of green tea. Indeed, a randomized, double-blind and efficacy study in Beijing China is under completion (2009), to determine the safety, tolerability and potential neuroprotective effects of a green tea polyphenol enriched preparation, in de novo PD patients without taking any anti-Parkinsonism drug (sponsored by the Michael J. Fox Foundation for Parkinson's Research). In accordance, another clinical efficacy study (sponsored by Charite University, Berlin, Germany) is aimed to evaluate whether a green tea extract containing 95\% EGCG, given daily as oral medication over a period of 12 months, has anti-inflammatory and neuroprotective properties in patients with relapsing-remitting multiple sclerosis assessed by magnetic resonance imaging and clinical examination (estimated study completion date is April 2009; U.S. FDA resources).

EGCG neuroprotective mechanism of action

\section{Preclinical studies}

Although evidence in human studies is limited, there are accumulated studies and reports on in vitro and animal models of aging and aged-related neurodegenerative diseases, demonstrated protective effects of green tea catechins. Neuroprotective in vivo studies employing the Parkinsonism-inducing neurotoxin, $N$-methyl-4-phenyl1,2,3,6-tetrahydropyridine (MPTP) have shown that both 
green tea extract and EGCG possess highly potent activities in preventing mice striatal dopamine (DA) depletion and substantia nigra (SN) dopaminergic neuron loss [60]. One possible mechanism underlying the effectiveness of green tea and EGCG against MPTP neurotoxicity may involve its catechol-like structure, as it is known that catechol-containing compounds are potent radical anti-oxidants and ferric ion chelator, such as R-apomorphine (R-APO) [27, 28, 30]. The catechol structural resemblance may account for a recently reported inhibitory effect of green tea polyphenols on $\left[{ }^{3} \mathrm{H}\right] \mathrm{DA}$ uptake by presynaptic transporters. This inhibition was suggested to block the metabolic product of MPTP, the neurotoxin 1-methyl-4-phenylpyridinium $\left(\mathrm{MPP}^{+}\right)$uptake (because of competition for the vesicular transporter) thereby protecting DA-containing neurons against $\mathrm{MPP}^{+}$-induced injury [89]. In vitro studies also demonstrated inhibition of $\mathrm{MPP}^{+}$and 6-hydroxydopamine (6-OHDA)-induced neurotoxicity by EGCG [59]. Furthermore, EGCG, at a low $\mathrm{IC}_{50}$ concentration $(0.2 \mu \mathrm{M})$, inhibited the activity of the enzyme catechol-O-methyltransferase (COMT) in rat liver cytosol homogenates [69]. DA and related catecholamines are physiological substrates of COMT. The COMT inhibitors, entacapone and tolcapone, clinically prescribed to PD-affected individuals, dosedependently inhibited the formation of the major metabolite of levodopa, 3-O-methyldopa, thereby improving its bioavailability in the brain [15]. In addition, iron accumulation has been implicated in a range of neurodegenerative disorders [111] and iron has been reported to accumulate in the neurons and microglia in SN of PD patients [98, 151]. Thus, the implication of the iron chelation property of EGCG in neuroprotection has been strengthened by the observations that both MPTP and 6-OHDA significantly increased iron levels in SN pars compacta (SNPC) of mice, rats and monkeys [79, 127].

Although AD epidemiological studies did not report any established outcome relative to green tea consumptions, in vitro observations showed that EGCG prevented amyloid beta peptides $(\mathrm{A} \beta)$-induced neurotoxicity $[11,58]$, and $\mathrm{EC}$ reduced nascent $\mathrm{A} \beta$ fibrils, elongation of the fibrils and destabilization of the formed assemblies [85]. In addition, EGCG was able to regulate the proteolytic processing of APP under in vivo and in vitro conditions [58, 96], suggesting that green tea polyphenols might be potentially promising therapeutic agents not only for PD, but also for AD. EGCG promoted the non-amyloidogenic $\alpha$-secretase pathway of APP in neuronal cell cultures resulting in a consequential augment in soluble $\operatorname{APP} \alpha(\operatorname{sAPP} \alpha)$ [58]. In addition, long-term treatment of mice with EGCG resulted in decreases in cell-associated, full-length APP levels, as well as increases in the sAPP $\alpha$ levels in the hippocampus [58]. New supportive data came from a study conducted in an Alzheimer's transgenic mice model ("Swedish" mutant
APP overexpressing, APPswTg), showing that EGCG promoted the generation of $\operatorname{sAPP} \alpha$ and decreased $\mathrm{A} \beta$ levels and plaques via promotion of the non-amyloidogenic $\alpha$-secretase proteolytic pathway [93, 94]. Recently, longterm administration of EGCG provided prophylactic benefits on rat spatial cognitive learning impairment caused by $\mathrm{A} \beta$ cerebral ventricle infusion [37], as well as prevented lipopolysaccharide-mediated neuronal cell death and memory impairment of mice, possibly through reduction of $\mathrm{A} \beta$ levels via inhibition of $\beta$ - and $\gamma$-secretases [57].

Supplementary preclinical models of other neurodegenerative diseases demonstrated that EGCG induced the prolongation of the symptom onset and life span and attenuated death signals in ALS mice model, expressing the human G93A mutated $\mathrm{Cu} / \mathrm{Zn}$-superoxide dismutase (SOD1) gene [54, 144]. Additionally, EGCG has been shown to be neuroprotective in aged rats [122] and in animal models of focal and global brain ischemia [91, 124, 125].

\section{ROS regulation and iron chelating activities}

It is well established that catechins possess free radical scavenging properties and act as biological antioxidants [82, 83, 90]. Catechins can scavenge both superoxide and hydroxyl radicals, as well as the 1,1-diphenyl-3-picrylhydrazyl radical, peroxyl radicals, nitric oxide, carbon-center free radicals, singlet oxygen and lipid free radicals, and peroxynitrite by preventing the nitration of tyrosine [30, $68,80,82,90,104,121,153]$. Additionally, these compounds can chelate metal ions, such as copper (II) and iron (III) to form inactive complexes and prevent the generation of potentially damaging free radicals [110]. Catechins have been found to be more efficient radical scavengers than vitamin $\mathrm{E}$ and $\mathrm{C}[82,90]$.

In the majority of the reports, EGCG was shown to be more efficient as a radical scavenger than its counterparts ECG, EC and EGC, which may be attributed to the presence of the trihydroxyl group on the $\mathrm{B}$ ring and the gallate moiety at the $3^{\prime}$ position in the $\mathrm{C}$ ring (Fig. 1) [31, 82, 83]. Previously, EGCG was shown to attenuate hydroxykynurenine (3-HK)-induced cell death and the increase in ROS concentrations and caspase-3 activity in neuronal culture, presumably via its antioxidant activity [48]. In rat brain tissue, green and black tea extracts were shown to inhibit lipid peroxidation promoted by iron-ascorbate in brain mitochondrial membranes [61]. A similar effect was also reported using brain synaptosomes, in which the four major green tea catechins were shown to inhibit iron-induced lipid peroxidation [30]. In this regard, it has been shown that EGCG attenuated paraquat-induced microsomal lipid peroxidation and increased the survival rate of paraquatpoisoned mice [41, 148]. In addition, Higuchi et al. [41] 
Fig. 1 Schematic diagram illustrating the antioxidative and iron chelating activities of EGCG. The neuroprotective effects of EGCG may involve inhibition of Fenton reaction and up-regulation of antioxidant enzymes, such as superoxide dismutase and catalase, resulted in attenuation of oxidative stress
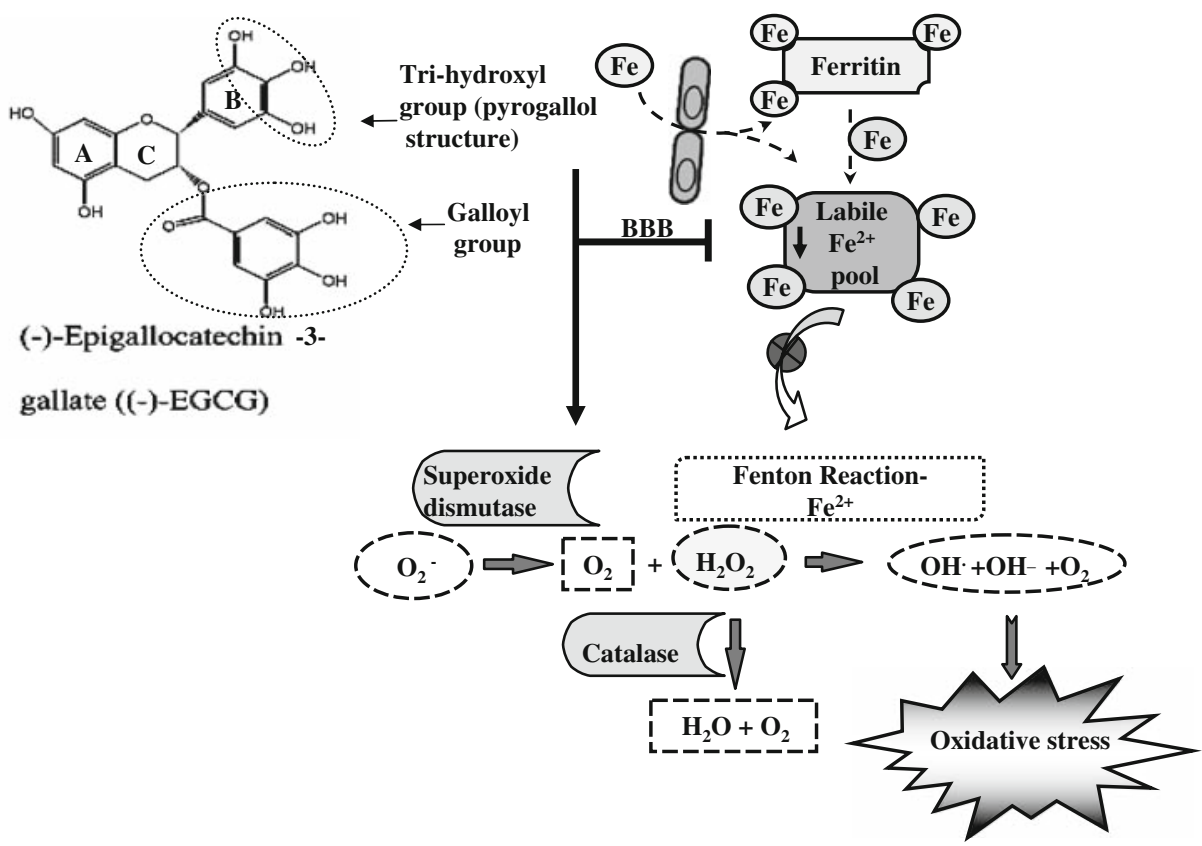

suggested that EGCG inhibited paraquate-induced malondialdehyde production in rat liver microsome system containing $\mathrm{FeSO}_{4}$ by two possible mechanisms: one was by scavenging of superoxide radicals, which were responsible for the reduction of ferric $\left(\mathrm{Fe}^{3+}\right)$ to ferrous $\left(\mathrm{Fe}^{2+}\right)$ catalyzed by the Fenton reaction. The other, was through ironchelating activity, given that the inhibition disappeared when excessive amount of $\mathrm{FeSO}_{4}$ was added to the reaction, indicating that EGCG inhibited iron driven lipid peroxidation by pulling out available iron. Thus, the protective effect of EGCG against neurological diseases may involve its radical scavenging and iron chelating activities. Additionally, the inhibition of enzymes, whose activity may promote OS, or an increase of antioxidant enzyme activities, might have beneficial significance to EGCG neuroprotection. Indeed, previous reports demonstrated that EGCG was found to elevate the activity of two major antioxidant enzymes, superoxide dismutase (SOD) and catalase in mice striatum [60] (Fig. 1).

The ability of green tea catechins and in particular EGCG, to chelate metal ions, such as iron and copper, may contribute to their antioxidant/neuroprotective activity by inhibiting transition metal-catalyzed free radical formation. The two points of attachment of transition metal ions to flavonoid molecules are: the o-diphenolic groups in the $3^{\prime}, 4^{\prime}$-dihydroxy positions in the $\mathrm{B}$ ring, and the keto structure 4-keto, 3-hydroxy or 4-keto and 5-hydroxy in the $\mathrm{C}$ ring of the flavonols (Fig. 1) [129, 130]. The ability of green tea catechins to act as relatively potent metal chelators [26, 30] may be of major significance for the treatment of neurodegenerative diseases, since iron accumulation has been shown in neurodegenerative brain areas [97]. Most importantly, green tea was reported not to affect iron absorption in healthy human subjects [10]. The localization of iron and ferritin in PD patients is restricted to specific brain areas [47, 97, 118] in the SNPC, but not the reticulata [47]. Similarly, AD pathogenesis is associated with iron accumulation and is linked to the characteristic neocortical $\mathrm{A} \beta$ deposition, phosphorylation of tau and tangle formation, which may be mediated by abnormal interaction with excess free-chelatable iron [22, 132]. Ionic iron can, in turn, participate in the Fenton reaction with subsequent generation of ROS, initiating the processes of OS and inflammatory cascade, resulting in the production of cytotoxic cytokines (tumor necrosis-alpha (TNF- $\alpha$ ), interluekins-1 and -6) in the microglia and surrounding neurons [78, 103] and activation of transcription factors and nuclear factor-kappa B (NF- $\kappa \mathrm{B})$ [66, 107]. Indeed, a marked increase in NF- $\kappa \mathrm{B}$ immunoreactivity was found in the nucleus of dopaminergic neurons of the Parkinsonian SNPC, compared to normal brains [43]. EGCG was found to inhibit the nuclear translocation of NF- $\kappa \mathrm{B}$ in in vitro systems: immunofluorescence and electromobility shift assays showed that introduction of green tea extract before 6-OHDA inhibited both NF- $\kappa \mathrm{B}$ nuclear translocation and binding activity in human neuroblastoma SH-SY5Y cells $[61,71]$. Furthermore, these reduced activity of NF- $\kappa$ B by EGCG and the theaflavin-3,3'-digallate polyphenol from black tea was associated with inhibition of lipopolysaccharide (LPS)-induced TNF- $\alpha$ production [147] and the enzyme inducible nitric oxide synthase (iNOS) [66, 67, 88], which is responsible for the production of the shortlive free radical, nitric oxide, in activated macrophages. 
Interestingly, recent studies have identified a novel link between iron and $\mathrm{AD}$, associated with an enhancement of endogenous APP translation and subsequent $\mathrm{A} \beta$ formation, via activation of an iron responsive element (IRE-type II) in the $5^{\prime}$ untranslated region (UTR) of APP mRNA [99]. Notably, recent study have demonstrated a significant increase of reactive astrocytosis and iNOS immunoreactivity, which was accompanied by neuronal damage in the temporal cortex and hippocampus of rats injected with $\mathrm{A} \beta$ (25-35) [63]. These findings opened a new potential therapeutic avenue aimed at reducing amyloidosis with radical scavenger and iron-chelating drugs that modulate APP mRNA translation. In support, a recent in vitro study demonstrated that EGCG reduced full-length APP in SH-SY5Y cells without altering APP mRNA levels, accompanied by dose-dependent increase in the level of the iron metabolism-related protein, TfR [96], which share also the consensus sequence for an IRE in the $3^{\prime}$-UTR of its mRNA [17]. Exogenous iron supplementation reversed EGCG effects, suggesting a post-transcriptional action, presumably by the mechanism of chelating intracellular iron pools (Fig. 1). This is further supported by the observation that EGCG suppressed translation of a luciferase reporter gene driven by the IRE-type II-containing sequences of APP [96]. Furthermore, it was found that EGCG markedly reduced secreted $\mathrm{A} \beta$ levels in the conditioned medium of Chinese hamster ovarian cells, overexpressing the "Swedish" mutated APP (CHO/DNL) [96] and in primary neuronal cells derived from transgenic mice bearing the APP "Swedish" mutation [94].

More recently, Friedlich et al. [19] have described a putative IRE in the $5^{\prime}$-UTR of PD-related $\alpha$-synuclein mRNA and predicted that this RNA structure may have a potential to function as a post-transcriptional regulator of its protein synthesis in response to iron and redox events, resembling the pattern seen with APP and the iron-associated proteins, ferritin and TfR. This finding can explain, in part, previous observation demonstrating that EGCG prevented iron-dependent up-regulation of $\alpha$-synuclein in the SNPC of MPTP-treated mice, resulting in neuroprotection of SN dopaminergic neurons [72]. Thus, the radical scavenging and free-iron chelating activities of green tea catechins may directly influence aggregation and deposition of either $\mathrm{A} \beta$ or $\alpha$-synuclein in brains of $\mathrm{AD}$ and $\mathrm{PD}$ patients, respectively.

\section{Regulation of hypoxia inducible factor (HIF)-1 alpha pathway}

An emerging target for neuroprotection associated with iron chelation implicates the activation of a hypoxia signal transduction pathway that culminates in the stabilization of the transcriptional activator HIF-1 and increased transcription of genes mediating compensatory survival processes in response to OS [46, 113]. The presence of HIF-1 within the cells is under the strict control of a class of iron-dependent and oxygen-sensor enzymes, named the HIF prolyl-4-hydroxylases [46]. This family of enzymes hydroxylates critical proline and asparagine residues in HIF upon high oxygen levels and iron overload, targeting it for degradation by the ubiquitin proteasome system (UPS). In this scheme, iron chelators would stabilize HIF-1 alpha, which in turn would heterodimerize with its partner, HIF-1 beta in the nucleus, bind to an hypoxia responsive element in regulatory genes and transactivate the expression of established protective genes, including the angiogenic vascular endothelial growth factor (VEGF), erythropoietin, p21 waf1/cip1, glucose transporter-1 and the glycolytic enzymes aldolase and enolase-1 [114, 150]. Indeed, EGCG and ECG were shown to induce HIF-1 alpha protein and HIF-1 activity and increase mRNA expression levels of glucose transporter 1 (GLUT-1), VEGF, and p21 waf1/cip1, whereas this effect was blocked by iron and ascorbate, indicating that these catechins may activate HIF-1 through the chelation of iron [128, 154]. Applying a neurorescue paradigm in neuronal culture, we have recently found that EGCG decreased mRNA transcript and protein levels of the beta-subunit of prolyl-4-hydroxylase and the protein levels of two molecular chaperones, which are associated with HIF-regulation/degradation, the immunoglobulinheavy-chain binding protein, BiP and the heat shock protein 90 (HSP90) [133, 134] (Fig. 2). In support, previous finding demonstrated that EGCG directly binds and inhibits HSP90 in mouse hepatoma cells [87]. Inhibition of HSP90 is considered a requirement for the rapid hypoxic stabilization of HIF-1 alpha, which otherwise might be degraded by unspecific pathway [44]. Thus, it is possible that the protective effect of EGCG under OS/hypoxic conditions may combine the suppression of hydroxyl radical formation via Fenton chemistry, as well as inhibition of irondependent prolyl hydroxylase.

Another link between hypoxia and iron is reflected by the hypoxic-mediated positive regulation of the iron regulatory proteins, IRP1 and IRP2 and consequential transactivation of their target mRNAs, ferritin and TfR. Interestingly, the free iron-induced proteasomal-mediated degradation of IRP2 involves also activation of a prolyl hydroxylase and is inhibited by iron chelators [35, 36, 131]. Thus, it is possible that IRP2 is a substrate for this enzyme, in a similar way as HIF, signaling it for protein degradation.

The reduction in the chelatable iron pool by EGCG may result in the inhibition of prolyl hydroxylase activity and consequently, in the concerted activation of both HIF and IRP2. As HIF-1 and IRPs coordinate the expression of a wide array of genes, involved in cellular iron homeostasis, 
Fig. 2 A proposed schematic model of the neuroprotective mechanism of action of (-)-epigallocatechin-3-gallate (EGCG). The diagram demonstrates the potential molecular pathways involved in the multifunctional effects of EGCG in neuronal tissues. Full discussion is in the text

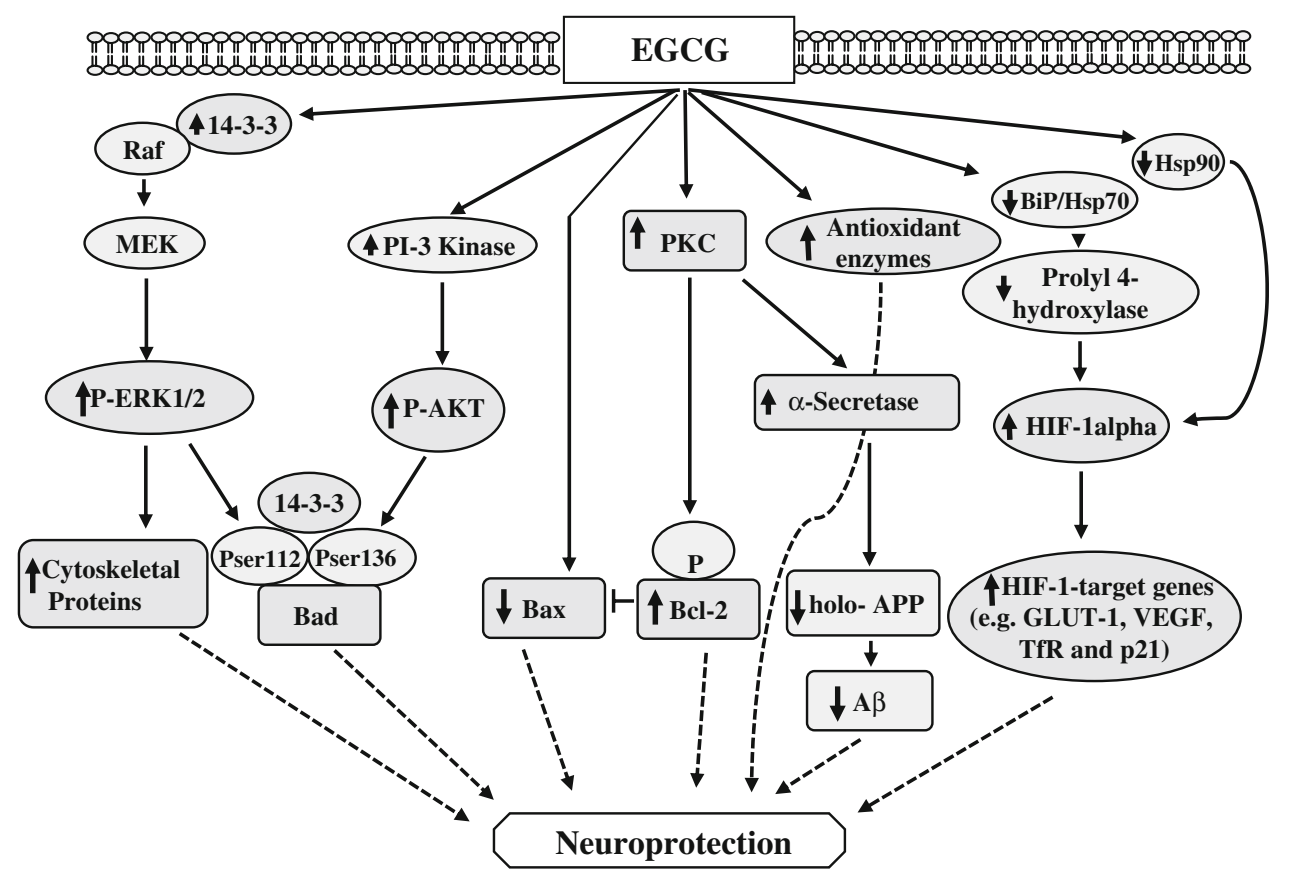

survival and proliferation [112], their activation could be of major importance in novel therapeutic strategy of neurodegenerative diseases. In support, recent findings suggest the application of low molecular weight or peptide inhibitors of the HIF prolyl 4-hydroxylases as novel neurological therapy [113].

\section{Regulation of cell signaling pathways promoting neuronal outgrowth}

Emerging evidence suggests that the iron chelating and antioxidant activities of green tea catechins cannot be the exclusive mechanism responsible for their neuroprotective action, but rather, their ability to alter signaling pathways may significantly contribute to the cell survival effect [120, 140]. Modulation of cellular survival and signal transduction pathways has significant biological consequences that are important in understanding the various pharmacological and toxicological responses of antioxidant drugs. A number of intracellular signaling pathways have been described to play central functions in EGCG-promoted neuronal protection against a variety of extracellular insults, such as the MAPK [115, 134, 143], PKC [14, 59, 95, 133] and phosphatidylinositol-3-kinase (PI-3 kinase)Akt pathways [50, 53, 73]), as described in Fig. 2. Given the critical role of MAPK pathways in regulating cellular processes that are affected in neurodegenerative diseases, the importance of MAPKs as transducers of extracellular stimuli into a series of intracellular phosphorylation is being increasingly recognized. OS seems to be a major stimulus for MAPK cascade, which might lead to cell survival/cell death. Previous in vitro studies demonstrated the potency of EGCG to induce ARE-mediated defensive genes and MAPKs pathways, including various cell survival signaling regulators, p44/42 ERK $1 / 2$, JNK and p38 MAPK $[8,86]$. The role of ERK1/2 signaling seems to be connected to attenuation of neuronal death and cellular injury by OS [106]. EGCG counteracted the decline in ERK1/2 induced by 6-OHDA [59] and induced phosphorylation of ERK1/2 in serum-deprived SH-SY5Y cells [134].

(-)-EGCG activity also involves the intracellular signaling mediator, PKC $[58,95]$, thought to have an essential role in the regulation of cell survival and programmed cell death $[16,70]$. A rapid loss of neuronal PKC activity is a common consequence of brain neurodegeneration $[4,6]$. The induction of PKC activity in neurons by EGCG $(1-10 \mu \mathrm{M})$ is thought to be a prerequisite for neuroprotection against several neurotoxins, such as $\mathrm{A} \beta$ [58], serum withdrawal [73, 95, 133] and 6-OHDA [59] since inhibition of PKC phosphorylation completely abolished the protection induced by EGCG and by the PKC activator, phorbol 12-myristate 13-acetate (PMA). These in vitro results were supported by a previous report [58], demonstrating that EGCG caused a significant increase of the levels of PKC isozymes, $\alpha$ and $\varepsilon$, in the membrane and cytosolic fractions of mice hippocampus. These isoforms play a crucial role in cell survival and differentiation pathways [29] and may be involved in APP regulatory processing associated with the pathogenesis of $\mathrm{AD}[2,116]$. Indeed, previous studies in brains of $\mathrm{AD}$ patients demonstrated reduction of $\mathrm{PKC} \varepsilon$ activity [77]. 
The mechanism by which PKC activation leads to neuroprotection begins to be elucidated. Studies with extraneuronal tissues support a role for $\mathrm{PKC} \alpha$ as a kinase of the antiapoptotic Bcl-2, probably through direct or indirect phosphorylation of this cell survival protein [101]. Neuroprotective experimental studies demonstrated that the protective effect of EGCG was associated with a reduced levels of the apoptotic markers, cleaved caspase 3; its downstream cleaved substrate poly-ADP-ribose-polymerase (PARP) and Bad [95, 137, 138]. This is supported by the observation that EGCG could not overcome neuronal death under PKC pathway blockade, suggesting that this cascade is essential for the neuroprotective and neurorescue effects of EGCG [95].

Recently, we have identified a novel pathway in the neuroprotective mechanism of action of EGCG, which involves a rapid $\mathrm{PKC}$-mediated degradation of Bad protein by the ubiquitin UPS in SH-SY5Y cells [49]. Bad has been suggested to link survival signals to the mitochondrial cell death machinery. Thus, the newly described role of Bad during the initial response to EGCG-induced cell signaling may illuminate the mechanism of neuroprotective/neurorescue action of EGCG. In addition, EGCG was shown to induce a rapid translocation of the isoform $\mathrm{PKC} \alpha$ to the membrane compartment in human astroglioma or rat pheochromocytoma PC12 cells $[52,95]$, as well as upregulation of $\mathrm{PKC} \varepsilon \mathrm{mRNA}$ expression and a concentration-dependent activation of $\mathrm{PKC} \varepsilon$ in serum-deprived in SH-SY5Y cells [133]. These findings are supported by animal studies showing that 2 weeks oral consumption of EGCG prevented the extensive depletion of PKC $\alpha$ and counteracted the robust increase of Bax protein in the striatum and SNPC of mice intoxicated with MPTP [73].

A previous study in human epidermal keratinocytes indicated that EGCG promoted cell survival by increasing the ratio of the pro-survival Bcl-2 to pro-apoptotic Bax and inducing phosphorylation of Bad through ERK and AKT signaling pathways [13]. Using mitogen-activated protein kinase 1 (MEK1) inhibitor (PD98059), EGCG induced only the phosphorylation of serine (Ser)136 of Bad, while using PI-3 kinase inhibitor (LY294002), EGCG induced only the phosphorylation of Ser112 of Bad. These results indicated that EGCG affects both the ERK pathway, which is involved in phosphorylation of Bad at Ser112 and the PI-3 kinase/AKT pathway, involved in phosphorylation of Bad at Ser136 (Fig. 2). Nonetheless, a study with high concentrations with EGCG reported cell proliferation arrest of tumor cells and inhibition of ERK1/2 and AKT phosphorylation, which was associated with reduced phosphorylation of Bad [102]. This biphasic mode of biological activity of EGCG relies on its concentration-dependent window of pharmacological action: EGCG exhibits prooxidant and pro-apoptotic activity at high concentrations, which are responsible for its anti-cancer-cell death effect, while lower doses exert neuroprotection against a wide spectrum of neurotoxic compounds [137, 138]. A biphasic mode of action has been described for most of the typical radical scavengers and antioxidants, such as ascorbic acid (vitamin C) [34] and iron chelators, such as R-APO [20]. When SH-SY5Y cells were challenged with 6-OHDA or reduced content of serum, a low concentration of EGCG $(<10 \mu \mathrm{M})$ abolished the induction of proapoptotic-related mRNAs and the decrease in Bcl-2, Bcl-w and Bcl-xL [61, 137, 138]. The neuroprotective effect of EGCG is thought to be mediated through down-regulation of pro-apoptotic genes, as shown for $\mathrm{mdm} 2$, caspase-1, cyclin-dependent kinase inhibitor p21 and TNF-related apoptosis-inducing ligand, TRAIL, rather than up-regulation of anti-apoptotic genes $[137,138]$. In support, a recent study has shown that at nanomolar concentrations, EC stimulated MAPK and PI-3 kinase signaling pathway, cAMP-response element binding (CREB) protein phosphorylation and ERKdependent cAMP responsive element activity in primary cortical neurons, while at micromolar concentrations, EC-mediated activation of protein kinase pathways was lost and there was an inhibition of CREB phosphorylation [108].

In addition, a recent proteomic study [134] has demonstrated that EGCG increased the levels of the cell signaling binding protein, 14-3-3 gamma. By their interaction with more than 100 binding partners, $14-3-3$ protein family members modulate the action of proteins that are involved in cell cycle and transcriptional control, signal transduction, intracellular trafficking, regulation of ion channels and expression of cytoskeletal components [3]. In this regards, the neurorescue/neuroprotective activity of EGCG may be associated with the induction of 14-3-3 gamma, interacting with kinases of the PKC pathway and Bad and consequently preventing neuronal death (Fig. 2) [49, 74, $95,134]$. A previous study has demonstrated that overexpression of 14-3-3 gamma contributed to the regulation of the dynamics of glial fibrillary acidic protein (GFAP) filaments, which may facilitate the stability of the cytoskeleton and thus, play a specific neuroprotective role in the brain of $\mathrm{AD}$ patients [18]. In fact, recent proteomic analysis showed that EGCG dose-dependently increased the expression levels of various stabilizer proteins of chromatin organization and DNA, histone $\mathrm{H} 1$ member 4 and cytoskeletal proteins, such as the actin binding protein, tropomyosin 3 and beta-tubulin IV [134]. Since cytoskeletal proteins play a crucial role in promoting neurite outgrowth [105], these results suggest that the induction of structural proteins by EGCG is associated with its differentiation features, including neurite extension, cell body elongation and up-regulation of the growth associated protein-43 (GAP-43) [95, 133]. These findings support the 
assumption that in addition to antioxidant and iron chelating activities, complementary mechanisms are involved in the neuroprotective effect of EGCG.

\section{Conclusions and viewpoints}

Two main aspects are significantly contributing to the raising concept viewing green tea consumption of relevance to brain health: the factors and events that influence the incidence and progression of $\mathrm{PD}$ and $\mathrm{AD}$ are becoming better defined and understood; in parallel, the experimental evidence documenting the neuroprotective properties of green tea catechins, both in cell culture and animal studies are persistently increasing. It becomes evident that syndromes, such as $\mathrm{AD}$ and $\mathrm{PD}$ will require multiple drug therapy to address the varied pathological aspects of the disease [136]. Therefore, the poly-pharmacological activities of green tea catechins may be of significance for neuroprotection. Earlier, viewed as a mere anti-inflammatory and antioxidant, EGCG is at the present time considered a multimodal acting molecule, invoking various cellular neuroprotection/neurorescue mechanisms including iron-chelation, scavenging of oxygen and nitrogen radical species and activation of PKC signaling pathway and pro-survival genes (Figs. 1, 2). Its non-toxic, lipophilic nature, and thus presumably brain permeable, is advocated for "remove iron" from those brain areas, where it preferentially accumulates in neurodegenerative diseases. Additionally, the chelation of reactive freeiron pool by EGCG and consequent reduction in APP translation would contribute to decrease $\mathrm{A} \beta$ generation/ fibrillization, which together with the promotion of the non-amyloidogenic pathway and induction of neurite outgrowth, may converge in a slowdown in the process of neuronal loss in $\mathrm{AD}$.

Another novel therapeutic approach may involve drug combinations, mixing target-acting compounds, thus providing a practical way to design specific polypharmacology. The complex symptomatology of neurodegenerative diseases often necessitates the use of more than one multifunctional drug. Over the years, it has become evident that some combinations do induce a favorable clinical response, not achieved by each of the drugs given alone [51]. Currently, choice of drug combinations is based on a trial and error paradigm guided by the clinical response. Understanding the biological principles, by which the combined treatments act, would provide insights into the pathological mechanisms of neurodegenerative disorders and enable a more "rational" selection of drugs. Indeed, recent narrative regimen study described a combined treatment of memantine, the first drug in a novel class of $\mathrm{AD}$ medications, and tea polyphenol, in excitotoxic mouse brain injury demonstrating significant neuroprotective effects of the combined treatment, compared with memantine and tea polyphenol treatment alone, including reduction in increased synaptosomal ROS and calcium concentration and attenuation of decreased anion channel ATPase activity and mitochondrial potential, accompanied with improved locomotor activity [9].

Our vision is to translate preclinical and clinical findings of green tea catechins into a lifestyle arena. Thus, future efforts in the understanding of the neuroprotective/neurorescue mechanism of action of EGCG must concentrate on deciphering specific cellular targets, and signaling cascades. Further preclinical studies are needed to clarify if EGCG and its metabolites, at sufficient concentrations, can reach the brain and regulate cell-signaling pathways and whether these effects can be successfully translated into prospect human studies to affect the progression of neurodegenerative disorders.

Acknowledgment We thank the support of Rappaport Family Research, Technion-Israel Institute of Technology.

\section{References}

1. Abd El Mohsen MM, Kuhnle G, Rechner AR, Schroeter H, Rose S, Jenner P, Rice-Evans CA (2002) Uptake and metabolism of epicatechin and its access to the brain after oral ingestion. Free Radic Biol Med 33:1693-1702

2. Benussi L, Govoni S, Gasparini L, Binetti G, Trabucchi M, Bianchetti A, Racchi M (1998) Specific role for protein kinase C alpha in the constitutive and regulated secretion of amyloid precursor protein in human skin fibroblasts. Neurosci Lett 240:97-101

3. Berg D, Holzmann C, Riess O (2003) 14-3-3 proteins in the nervous system. Nat Rev Neurosci 4:752-762

4. Busto R, Globus MY, Neary JT, Ginsberg MD (1994) Regional alterations of protein kinase $\mathrm{C}$ activity following transient cerebral ischemia: effects of intraischemic brain temperature modulation. J Neurochem 63:1095-1103

5. Cabrera C, Artacho R, Gimenez R (2006) Beneficial effects of green tea-a review. J Am Coll Nutr 25:79-99

6. Cardell M, Wieloch T (1993) Time course of the translocation and inhibition of protein kinase $\mathrm{C}$ during complete cerebral ischemia in the rat. J Neurochem 61:1308-1314

7. Checkoway H, Powers K, Smith-Weller T, Franklin GM, Longstreth WT Jr, Swanson PD (2002) Parkinson's disease risks associated with cigarette smoking, alcohol consumption, and caffeine intake. Am J Epidemiol 155:732-738

8. Chen C, Yu R, Owuor ED, Kong AN (2000) Activation of antioxidant-response element (ARE), mitogen-activated protein kinases (MAPKs) and caspases by major green tea polyphenol components during cell survival and death. Arch Pharm Res 23:605-612

9. Chen CM, Lin JK, Liu SH, Lin-Shiau SY (2008) Novel regimen through combination of memantine and tea polyphenol for neuroprotection against brain excitotoxicity. J Neurosci Res $86: 2696-2704$

10. Cheng TO (2009) Green tea does not inhibit iron absorption. Int J Cardiol 133:112

11. Choi YT, Jung CH, Lee SR, Bae JH, Baek WK, Suh MH, Park J, Park CW, Suh SI (2001) The green tea polyphenol 
(-)-epigallocatechin gallate attenuates beta-amyloid-induced neurotoxicity in cultured hippocampal neurons. Life Sci 70:603614

12. Chu KO, Wang CC, Chu CY, Choy KW, Pang CP, Rogers MS (2007) Uptake and distribution of catechins in fetal organs following in utero exposure in rats. Hum Reprod 22:280-287

13. Chung JH, Han JH, Hwang EJ, Seo JY, Cho KH, Kim KH, Youn JI, Eun HC (2003) Dual mechanisms of green tea extractinduced cell survival in human epidermal keratinocytes. Faseb J 13:1913-1915

14. Cordey M, Gundimeda U, Gopalakrishna R, Pike CJ (2003) Estrogen activates protein kinase $\mathrm{C}$ in neurons: role in neuroprotection. J Neurochem 84:1340-1348

15. Deleu D, Northway MG, Hanssens Y (2002) Clinical pharmacokinetic and pharmacodynamic properties of drugs used in the treatment of Parkinson's disease. Clin Pharmacokinet 41:261309

16. Dempsey EC, Newton AC, Mochly-Rosen D, Fields AP, Reyland ME, Insel PA, Messing RO (2000) Protein kinase C isozymes and the regulation of diverse cell responses. Am J Physiol Lung Cell Mol Physiol 279:L429-L438

17. Erlitzki R, Long JC, Theil EC (2002) Multiple, conserved ironresponsive elements in the $3^{\prime}$-untranslated region of transferrin receptor mRNA enhance binding of iron regulatory protein 2 . J Biol Chem 277:42579-42587

18. Fountoulakis M, Cairns N, Lubec G (1999) Increased levels of 14-3-3 gamma and epsilon proteins in brain of patients with Alzheimer's disease and Down syndrome. J Neural Transm Suppl 57:323-335

19. Friedlich AL, Tanzi RE, Rogers JT (2007) The 5'-untranslated region of Parkinson's disease alpha-synuclein messengerRNA contains a predicted iron responsive element. Mol Psychiatry $12: 222-223$

20. Gassen M, Gross A, Youdim MB (1998) Apomorphine enantiomers protect cultured pheochromocytoma (PC12) cells from oxidative stress induced by $\mathrm{H}_{2} \mathrm{O}_{2}$ and 6-hydroxydopamine. Mov Disord 13:242-248

21. Gawande S, Kale A, Kotwal S (2008) Effect of nutrient mixture and black grapes on the pharmacokinetics of orally administered (-)epigallocatechin-3-gallate from green tea extract: a human study. Phytother Res 22:802-808

22. Gong CX, Iqbal K (2008) Hyperphosphorylation of microtubule-associated protein tau: a promising therapeutic target for Alzheimer disease. Curr Med Chem 15:2321-2328

23. Gotz ME, Freyberger A, Riederer P (1990) Oxidative stress: a role in the pathogenesis of Parkinson's disease. J Neural Transm Suppl 29:241-249

24. Gotz ME, Kunig G, Riederer P, Youdim MB (1994) Oxidative stress: free radical production in neural degeneration. Pharmacol Ther 63:37-122

25. Graham HN (1992) Green tea composition, consumption, and polyphenol chemistry. Prev Med 21:334-350

26. Grinberg LN, Newmark H, Kitrossky N, Rahamim E, Chevion M, Rachmilewitz EA (1997) Protective effects of tea polyphenols against oxidative damage to red blood cells. Biochem Pharmacol 54:973-978

27. Grunblatt E, Mandel S, Berkuzki T, Youdim MBH (1999) Apomorphine protects against MPTP-induced neurotoxicity in mice. Mov Disord 14:612-618

28. Grunblatt E, Mandel S, Maor G, Youdim MBH (2001) Effects of $\mathrm{R}$-apomorphine and S-apomorphine on MPTP-induced nigrostriatal dopamine neuronal loss. J Neurochem 77:146-156

29. Gubina E, Rinaudo MS, Szallasi Z, Blumberg PM, Mufson RA (1998) Overexpression of protein kinase $C$ isoform epsilon but not delta in human interleukin-3-dependent cells suppresses apoptosis and induces bcl-2 expression. Blood 91:823-829
30. Guo Q, Zhao B, Li M, Shen S, Xin W (1996) Studies on protective mechanisms of four components of green tea polyphenols against lipid peroxidation in synaptosomes. Biochim Biophys Acta 1304:210-222

31. Guo Q, Zhao B, Shen S, Hou J, Hu J, Xin W (1999) ESR study on the structure-antioxidant activity relationship of tea catechins and their epimers. Biochim Biophys Acta 1427:13-23

32. Halliwell B (1992) Reactive oxygen species and the central nervous system. J Neurochem 59:1609-1623

33. Halliwell B (2001) Role of free radicals in the neurodegenerative diseases: therapeutic implications for antioxidant treatment. Drugs Aging 18:685-716

34. Halliwell B (1996) Vitamin C: antioxidant or pro-oxidant in vivo? Free Radic Res 25:439-454

35. Hanson ES, Foot LM, Leibold EA (1999) Hypoxia post-translationally activates iron-regulatory protein 2. J Biol Chem 274:5047-5052

36. Hanson ES, Leibold EA (1999) Regulation of the iron regulatory proteins by reactive nitrogen and oxygen species. Gene Expr 7:367-376

37. Haque AM, Hashimoto M, Katakura M, Hara Y, Shido O (2008) Green tea catechins prevent cognitive deficits caused by Abe$\operatorname{ta}(1-40)$ in rats. J Nutr Biochem 19:619-626

38. Harada M, Kan Y, Naoki H, Fukui Y, Kageyama N, Nakai M, Miki W, Kiso Y (1999) Identification of the major antioxidative metabolites in biological fluids of the rat with ingested (+)-catechin and (-)-epicatechin. Biosci Biotechnol Biochem 63:973-977

39. Hellenbrand W, Seidler A, Boeing H, Robra BP, Vieregge P, Nischan P, Joerg J, Oertel WH, Schneider E, Ulm G (1996) Diet and Parkinson's disease. I: A possible role for the past intake of specific foods and food groups. Results from a self-administered food-frequency questionnaire in a case-control study. Neurology 47:636-643

40. Higdon JV, Frei B (2003) Tea catechins and polyphenols: health effects, metabolism, and antioxidant functions. Crit Rev Food Sci Nutr 43:89-143

41. Higuchi A, Yonemitsu K, Koreeda A, Tsunenari S (2003) Inhibitory activity of epigallocatechin gallate (EGCG) in paraquat-induced microsomal lipid peroxidation-a mechanism of protective effects of EGCG against paraquat toxicity. Toxicology 183:143-149

42. Hollman PC, Feskens EJ, Katan MB (1999) Tea flavonols in cardiovascular disease and cancer epidemiology. Proc Soc Exp Biol Med 220:198-202

43. Hunot S, Brugg B, Ricard D, Michel PP, Muriel MP, Ruberg M, Faucheux BA, Agid Y, Hirsch EC (1997) Nuclear translocation of NF-kappaB is increased in dopaminergic neurons of patients with Parkinson disease. Proc Natl Acad Sci USA 94:7531-7536

44. Ibrahim NO, Hahn T, Franke C, Stiehl DP, Wirthner R, Wenger RH, Katschinski DM (2005) Induction of the hypoxia-inducible factor system by low levels of heat shock protein 90 inhibitors. Cancer Res 65:11094-11100

45. Ishige K, Schubert D, Sagara Y (2001) Flavonoids protect neuronal cells from oxidative stress by three distinct mechanisms. Free Radic Biol Med 30:433-446

46. Jaakkola P, Mole DR, Tian YM, Wilson MI, Gielbert J, Gaskell SJ, Kriegsheim A, Hebestreit HF, Mukherji M, Schofield CJ, Maxwell PH, Pugh CW, Ratcliffe PJ (2001) Targeting of HIFalpha to the von Hippel-Lindau ubiquitylation complex by $\mathrm{O}_{2}$-regulated prolyl hydroxylation. Science $292: 468-472$

47. Jellinger K, Paulus W, Grundke-Iqbal I, Riederer P, Youdim MBH (1990) Brain iron and ferritin in Parkinson's and Alzheimer's diseases. J Neural Transm Park Dis Dement Sect $2: 327-340$ 
48. Jeong JH, Kim HJ, Lee TJ, Kim MK, Park ES, Choi BS (2004) Epigallocatechin 3-gallate attenuates neuronal damage induced by 3-hydroxykynurenine. Toxicology 195:53-60

49. Kalfon L, Youdim MB, Mandel SA (2007) Green tea polyphenol (-)-epigallocatechin-3-gallate promotes the rapid protein kinase C- and proteasome-mediated degradation of Bad: implications for neuroprotection. J Neurochem 100:992-1002

50. Kaplan DR, Miller FD (2000) Neurotrophin signal transduction in the nervous system. Curr Opin Neurobiol 10:381-391

51. Keith CT, Borisy AA, Stockwell BR (2005) Multicomponent therapeutics for networked systems. Nat Rev Drug Discov 4:7178

52. Kim SY, Ahn BH, Kim J, Bae YS, Kwak JY, Min G, Kwon TK, Chang JS, Lee YH, Yoon SH, Min DS (2004) Phospholipase C, protein kinase $\mathrm{C}, \mathrm{Ca} 2+$ /calmodulin-dependent protein kinase II, and redox state are involved in epigallocatechin gallate-induced phospholipase D activation in human astroglioma cells. Eur $\mathbf{J}$ Biochem 271:3470-3480

53. Koh SH, Kim SH, Kwon H, Park Y, Kim KS, Song CW, Kim J, Kim MH, Yu HJ, Henkel JS, Jung HK (2003) Epigallocatechin gallate protects nerve growth factor differentiated PC12 cells from oxidative-radical-stress-induced apoptosis through its effect on phosphoinositide 3-kinase/Akt and glycogen synthase kinase-3. Brain Res Mol Brain Res 118:72-81

54. Koh SH, Lee SM, Kim HY, Lee KY, Lee YJ, Kim HT, Kim J, Kim MH, Hwang MS, Song C, Yang KW, Lee KW, Kim SH, $\mathrm{Kim} \mathrm{OH}$ (2006) The effect of epigallocatechin gallate on suppressing disease progression of ALS model mice. Neurosci Lett 395:103-107

55. Kuriyama S, Hozawa A, Ohmori K, Shimazu T, Matsui T, Ebihara S, Awata S, Nagatomi R, Arai H, Tsuji I (2006) Green tea consumption and cognitive function: a cross-sectional study from the Tsurugaya Project 1 . Am J Clin Nutr 83:355-361

56. Lau FC, Shukitt-Hale B, Joseph JA (2005) The beneficial effects of fruit polyphenols on brain aging. Neurobiol Aging 26(Suppl 1): $128-132$

57. Lee YK, Yuk DY, Lee JW, Lee SY, Ha TY, Oh KW, Yun YP, Hong JT (2009) (-)-Epigallocatechin-3-gallate prevents lipopolysaccharide-induced elevation of beta-amyloid generation and memory deficiency. Brain Res 1250:164-174

58. Levites Y, Amit T, Mandel S, Youdim MBH (2003) Neuroprotection and neurorescue against amyloid beta toxicity and PKC-dependent release of non-amyloidogenic soluble precursor protein by green tea polyphenol (-)-epigallocatechin-3-gallate. FASEB J 17:952-954

59. Levites Y, Amit T, Youdim MBH, Mandel S (2002) Involvement of protein kinase $\mathrm{C}$ activation and cell survival/cell cycle genes in green tea polyphenol (-)-epigallocatechin-3-gallate neuroprotective action. J Biol Chem 277:30574-30580

60. Levites Y, Weinreb O, Maor G, Youdim MBH, Mandel S (2001) Green tea polyphenol (-)- Epigallocatechin-3-gallate prevents $\mathrm{N}$-methyl-4-phenyl-1, 2, 3, 6-tetrahydropyridine-induced dopaminergic neurodegeneration. J Neurochem 78:1073-1082

61. Levites Y, Youdim MBH, Maor G, Mandel S (2002) Attenuation of 6-hydroxydopamine (6-OHDA)-induced nuclear factorkappaB (NF-kappaB) activation and cell death by tea extracts in neuronal cultures. Biochem Pharmacol 63:21-29

62. Li C, Lee MJ, Sheng S, Meng X, Prabhu S, Winnik B, Huang B, Chung JY, Yan S, Ho CT, Yang CS (2000) Structural identification of two metabolites of catechins and their kinetics in human urine and blood after tea ingestion. Chem Res Toxicol $13: 177-184$

63. Limon ID, Diaz A, Mendieta L, Chamorro G, Espinosa B, Zenteno E, Guevara J (2009) Amyloid-beta(25-35) impairs memory and increases NO in the temporal cortex of rats. Neurosci Res 963:129-137
64. Lin AM, Chyi BY, Wu LY, Hwang LS, Ho LT (1998) The antioxidative property of green tea against iron-induced oxidative stress in rat brain. Chin J Physiol 41:189-194

65. Lin LC, Wang MN, Tseng TY, Sung JS, Tsai TH (2007) Pharmacokinetics of (-)-epigallocatechin-3-gallate in conscious and freely moving rats and its brain regional distribution. J Agric Food Chem 55:1517-1524

66. Lin YL, Lin JK (1997) (-)-Epigallocatechin-3-gallate blocks the induction of nitric oxide synthase by down-regulating lipopolysaccharide-induced activity of transcription factor nuclear factor-kappaB. Mol Pharmacol 52:465-472

67. Lin YL, Tsai SH, Lin-Shiau SY, Ho CT, Lin JK (1999) Theaflavin-3, 3'-digallate from black tea blocks the nitric oxide synthase by down-regulating the activation of NF-kappaB in macrophages. Eur J Pharmacol 367:379-388

68. Lin YS, Tsai YJ, Tsay JS, Lin JK (2003) Factors affecting the levels of tea polyphenols and caffeine in tea leaves. J Agric Food Chem 51:1864-1873

69. Lu H, Meng X, Yang CS (2003) Enzymology of methylation of tea catechins and inhibition of catechol-O-methyltransferase by (-)-epigallocatechin gallate. Drug Metab Dispos 31:572-579

70. Maher P (2001) How protein kinase C activation protects nerve cells from oxidative stress-induced cell death. J Neurosci 21:2929-2938

71. Mandel S, Levites Y, Maor G, Youdim MBH (2000) Neuroprotection by black and green tea extracts involves inhibition of translocation and activity of NfkappaB in neuronal cells. Neurosci Lett Suppl 55:S35

72. Mandel S, Maor G, Youdim MB (2004) Iron and alpha-synuclein in the substantia nigra of MPTP-treated mice: effect of neuroprotective drugs R-apomorphine and green tea polyphenol (-)-epigallocatechin-3-gallate. J Mol Neurosci 24:401-416

73. Mandel S, Reznichenko L, Amit T, Youdim MB (2003) Green tea polyphenol (-)-epigallocatechin-3-gallate protects rat PC12 cells from apoptosis induced by serum withdrawal independent of P13-Akt pathway. Neurotox Res 5:419-424

74. Mandel S, Weinreb O, Amit T, Youdim MB (2004) Cell signaling pathways in the neuroprotective actions of the green tea polyphenol (-)-epigallocatechin-3-gallate: implications for neurodegenerative diseases. J Neurochem 88:1555-1569

75. Mandel S, Weinreb O, Reznichenko L, Kalfon L, Amit T (2006) Green tea catechins as brain-permeable, non toxic iron chelators to "iron out iron" from the brain. J Neural Transm Suppl:249257

76. Mandel SA, Avramovich-Tirosh Y, Reznichenko L, Zheng H, Weinreb O, Amit T, Youdim MB (2005) Multifunctional activities of green tea catechins in neuroprotection. Modulation of cell survival genes, iron-dependent oxidative stress and PKC signaling pathway. Neuro-Signals 14:46-60

77. Matsushima H, Shimohama S, Chachin M, Taniguchi T, Kimura $\mathrm{J}$ (1996) Ca2+-dependent and Ca2+-independent protein kinase $\mathrm{C}$ changes in the brain of patients with Alzheimer's disease. J Neurochem 67:317-323

78. Mogi M, Harada M, Riederer P, Narabayashi H, Fujita K, Nagatsu T (1994) Tumor necrosis factor-alpha (TNF-alpha) increases both in the brain and in the cerebrospinal fluid from parkinsonian patients. Neurosci Lett 165:208-210

79. Monteiro HP, Winterbourn CC (1989) 6-Hydroxydopamine releases iron from ferritin and promotes ferritin-dependent lipid peroxidation. Biochem Pharmacol 38:4177-4182

80. Morel I, Lescoat G, Cogrel P, Sergent O, Pasdeloup N, Brissot P, Cillard P, Cillard J (1999) Antioxidant and iron-chelating activities of the flavonoids catechin, quercetin and diosmetin on ironloaded rat hepatocyte cultures. Biochem Pharmacol 45:13-19

81. Nakagawa K, Miyazawa T (1997) Chemiluminescence-highperformance liquid chromatographic determination of tea 
catechin, (-)-epigallocatechin 3-gallate, at picomole levels in rat and human plasma. Anal Biochem 248:41-49

82. Nanjo F, Goto K, Seto R, Suzuki M, Sakai M, Hara Y (1996) Scavenging effects of tea catechins and their derivatives on 1, 1-diphenyl-2-picrylhydrazyl radical. Free Radic Biol Med 21:895-902

83. Nanjo F, Mori M, Goto K, Hara Y (1999) Radical scavenging activity of tea catechins and their related compounds. Biosci Biotechnol Biochem 63:1621-1623

84. Ng TP, Feng L, Niti M, Kua EH, Yap KB (2008) Tea consumption and cognitive impairment and decline in older Chinese adults. Am J Clin Nutr 88:224-231

85. Ono K, Yoshiike Y, Takashima A, Hasegawa K, Naiki H, Yamada M (2003) Potent anti-amyloidogenic and fibril-destabilizing effects of polyphenols in vitro: implications for the prevention and therapeutics of Alzheimer's disease. J Neurochem 87:172-181

86. Owuor ED, Kong AN (2002) Antioxidants and oxidants regulated signal transduction pathways. Biochem Pharmacol 64:765-770

87. Palermo CM, Westlake CA, Gasiewicz TA (2005) Epigallocatechin gallate inhibits aryl hydrocarbon receptor gene transcription through an indirect mechanism involving binding to a $90 \mathrm{kDa}$ heat shock protein. Biochemistry 44:5041-5052

88. Pan MH, Lin-Shiau SY, Ho CT, Lin JH, Lin JK (2000) Suppression of lipopolysaccharide-induced nuclear factor kappaB activity by theaflavin- $3,3^{\prime}$-digallate from black tea and other polyphenols through down-regulation of IkappaB kinase activity in macrophages. Biochem Pharmacol 59:357-367

89. Pan T, Fei J, Zhou X, Jankovic J, Le W (2003) Effects of green tea polyphenols on dopamine uptake and on MPP+-induced dopamine neuron injury. Life Sci 72:1073-1083

90. Pannala AS, Rice-Evans CA, Halliwell B, Singh S (1997) Inhibition of peroxynitrite-mediated tyrosine nitration by catechin polyphenols. Biochem Biophys Res Commun 232:164-168

91. Park D, Jeon JH, Shin S, Joo SS, Kang DH, Moon SH, Jang MJ, Cho YM, Kim JW, Ji HJ, Ahn B, Oh KW, Kim YB (2009) Green tea extract increases cyclophosphamide-induced teratogenesis by modulating the expression of cytochrome P-450 mRNA. Reprod toxicol 27:79-84

92. Pietta PG, Simonetti P, Gardana C, Brusamolino A, Morazzoni P, Bombardelli E (1998) Catechin metabolites after intake of green tea infusions. Biofactors 8:111-118

93. Rezai-Zadeh K, Arendash GW, Hou H, Fernandez F, Jensen M, Runfeldt M, Shytle RD, Tan J (2008) Green tea epigallocatechin-3-gallate (EGCG) reduces beta-amyloid mediated cognitive impairment and modulates tau pathology in Alzheimer transgenic mice. Brain Res 1214:177-187

94. Rezai-Zadeh K, Shytle D, Sun N, Mori T, Hou H, Jeanniton D, Ehrhart J, Townsend K, Zeng J, Morgan D, Hardy J, Town T, Tan J (2005) Green tea epigallocatechin-3-gallate (EGCG) modulates amyloid precursor protein cleavage and reduces cerebral amyloidosis in Alzheimer transgenic mice. J Neurosci 25:8807-8814

95. Reznichenko L, Amit T, Youdim MB, Mandel S (2005) Green tea polyphenol (-)-epigallocatechin-3-gallate induces neurorescue of long-term serum-deprived PC12 cells and promotes neurite outgrowth. J Neurochem 93:1157-1167

96. Reznichenko L, Amit T, Zheng H, Avramovich-Tirosh Y, Youdim MB, Weinreb O, Mandel S (2006) Reduction of ironregulated amyloid precursor protein and beta-amyloid peptide by (-)-epigallocatechin-3-gallate in cell cultures: implications for iron chelation in Alzheimer's disease. J Neurochem 97:527536

97. Riederer P, Sofic E, Rausch WD, Schmidt B, Reynolds GP, Jellinger K, Youdim MBH (1989) Transition metals, ferritin, glutathione, and ascorbic acid in parkinsonian brains. J Neurochem 52:515-520

98. Riederer P, Youdim MBH, Ben-Shachar D, Reichmann H, Jellinger K (1990) The implications of increased iron in parkinsonian substantia nigra and its high affinity binding to melanin for dopamine neuron degeneration. Eur J Pharmacol 183:3-4

99. Rogers JT, Randall JD, Cahill CM, Eder PS, Huang X, Gunshin H, Leiter L, McPhee J, Sarang SS, Utsuki T, Greig NH, Lahiri DK, Tanzi RE, Bush AI, Giordano T, Gullans SR (2002) An iron-responsive element type II in the $5^{\prime}$-untranslated region of the Alzheimer's amyloid precursor protein transcript. J Biol Chem 277:45518-45528

100. Rossi L, Mazzitelli S, Arciello M, Capo CR, Rotilio G (2008) Benefits from dietary polyphenols for brain aging and Alzheimer's disease. Neurochem Res 33:2390-2400

101. Ruvolo PP, Deng X, Carr BK, May WS (1998) A functional role for mitochondrial protein kinase Calpha in $\mathrm{Bcl} 2$ phosphorylation and suppression of apoptosis. J Biol Chem 273:25436-25442

102. Sah JF, Balasubramanian S, Eckert RL, Rorke EA (2003) Epigallocatechin-3-gallate inhibits epidermal growth factor receptor signaling pathway: evidence for direct inhibition of ERK1/2 and AKT kinases. J Biol Chem 279:12755-12762

103. Sakaguchi S, Furusawa S, Yokota K, Sasaki K, Takayanagi M, Takayanagi Y (1996) The enhancing effect of tumour necrosis factor-alpha on oxidative stress in endotoxemia. Pharmacol Toxicol 79:259-265

104. Salah N, Miller NJ, Paganga G, Tijburg L, Bolwell GP, RiceEvans C (1995) Polyphenolic flavanols as scavengers of aqueous phase radicals and as chain-breaking antioxidants. Arch Biochem Biophys 322:339-346

105. Satoh J, Yamamura T, Arima K (2004) The 14-3-3 protein epsilon isoform expressed in reactive astrocytes in demyelinating lesions of multiple sclerosis binds to vimentin and glial fibrillary acidic protein in cultured human astrocytes. Am J Pathol 165:577-592

106. Satoh T, Nakatsuka D, Watanabe Y, Nagata I, Kikuchi H, Namura S (2000) Neuroprotection by MAPK/ERK kinase inhibition with U0126 against oxidative stress in a mouse neuronal cell line and rat primary cultured cortical neurons. Neurosci Lett 288:163-166

107. Schreck R, Rieber P, Baeuerle PA (1991) Reactive oxygen intermediates as apparently widely used messengers in the activation of the NF-kappa B transcription factor and HIV-1. EMBO J 10:2247-2258

108. Schroeter H, Bahia P, Spencer JP, Sheppard O, Rattray M, Cadenas E, Rice-Evans C, Williams RJ (2007) (-)Epicatechin stimulates ERK-dependent cyclic AMP response element activity and up-regulates GluR2 in cortical neurons. J Neurochem 101:1596-1606

109. Schroeter H, Boyd C, Spencer JP, Williams RJ, Cadenas E, Rice-Evans C (2002) MAPK signaling in neurodegeneration: influences of flavonoids and of nitric oxide. Neurobiol Aging 23:861-880

110. Seeram NP, Henning SM, Niu Y, Lee R, Scheuller HS, Heber D (2006) Catechin and caffeine content of green tea dietary supplements and correlation with antioxidant capacity. J Agric Food Chem 54:1599-1603

111. Senior K (2001) New genes reveal major role for iron in neurodegeneration. Lancet 358:302

112. Sharp FR, Bernaudin M (2004) HIF1 and oxygen sensing in the brain. Nat Rev 5:437-448

113. Siddiq A, Aminova LR, Ratan RR (2007) Hypoxia inducible factor prolyl 4-hydroxylase enzymes: center stage in the battle against hypoxia, metabolic compromise and oxidative stress. Neurochem Res 32:931-946 
114. Siddiq A, Ayoub IA, Chavez JC, Aminova L, Shah S, LaManna JC, Patton SM, Connor JR, Cherny RA, Volitakis I, Bush AI, Langsetmo I, Seeley T, Gunzler V, Ratan RR (2005) Hypoxiainducible factor prolyl 4-hydroxylase inhibition. A target for neuroprotection in the central nervous system. J Biol Chem 280:41732-41743

115. Singer CA, Figueroa-Masot XA, Batchelor RH, Dorsa DM (1999) The mitogen-activated protein kinase pathway mediates estrogen neuroprotection after glutamate toxicity in primary cortical neurons. J Neurosci 19:2455-2463

116. Slack BE, Nitsch RM, Livneh E, Kunz GM Jr, Breu J, Eldar H, Wurtman RJ (1993) Regulation by phorbol esters of amyloid precursor protein release from Swiss 3T3 fibroblasts overexpressing protein kinase C alpha. J Biol Chem 268:2109721101

117. Slikker W, Youdim MB, Palmer GC, Hall E, Williams C, Trembly B (1999) The future of neuroprotection. Ann N Y Acad Sci 890:529-533

118. Sofic E, Paulus W, Jellinger K, Riederer P, Youdim MBH (1991) Selective increase of iron in substantia nigra zona compacta of parkinsonian brains. J Neurochem 56:978-982

119. Spencer JP (2008) Flavonoids: modulators of brain function? $\mathrm{Br}$ J Nutr 99(Suppl 1):ES60-ES77

120. Spencer JP (2007) The interactions of flavonoids within neuronal signalling pathways. Genes Nutr 2:257-273

121. Spencer JP, Schroeter H, Rechner AR, Rice-Evans C (2001) Bioavailability of flavan-3-ols and procyanidins: gastrointestinal tract influences and their relevance to bioactive forms in vivo. Antioxid Redox Signal 3:1023-1039

122. Srividhya R, Jyothilakshmi V, Arulmathi K, Senthilkumaran V, Kalaiselvi P (2008) Attenuation of senescence-induced oxidative exacerbations in aged rat brain by (-)-epigallocatechin-3gallate. Int J Dev Neurosci 26:217-223

123. Suganuma M, Okabe $S$, Oniyama M, Tada $Y$, Ito H, Fujiki H (1998) Wide distribution of $[3 \mathrm{H}](-)$-epigallocatechin gallate, a cancer preventive tea polyphenol, in mouse tissue. Carcinogenesis 19:1771-1776

124. Sutherland BA, Rahman RM, Appleton I (2006) Mechanisms of action of green tea catechins, with a focus on ischemia-induced neurodegeneration. J Nutr Biochem 17:291-306

125. Sutherland BA, Shaw OM, Clarkson AN, Jackson DN, Sammut IA, Appleton I (2005) Neuroprotective effects of (-)-epigallocatechin gallate following hypoxia-ischemia-induced brain damage: novel mechanisms of action. Faseb J 19:258-260

126. Tan LC, Koh WP, Yuan JM, Wang R, Au WL, Tan JH, Tan EK, Yu MC (2008) Differential effects of black versus green tea on risk of Parkinson's disease in the Singapore Chinese Health Study. Am J Epidemiol 167:553-560

127. Temlett JA, Landsberg JP, Watt F, Grime GW (1994) Increased iron in the substantia nigra compacta of the MPTP-lesioned hemiparkinsonian African green monkey: evidence from proton microprobe elemental microanalysis. J Neurochem 62:134-146

128. Thomas R, Kim MH (2005) Epigallocatechin gallate inhibits HIF-1alpha degradation in prostate cancer cells. Biochem Biophys Res Commun 334:543-548

129. Thompson M, Williams CR, Elliot GE (1976) Stability of flavonoid complexes of copper(II) and flavonoid antioxidant activity. Anal Chim Acta 85:375-381

130. van Acker SA, van den Berg DJ, Tromp MN, Griffioen DH, van Bennekom WP, van der Vijgh WJ, Bast A (1996) Structural aspects of antioxidant activity of flavonoids. Free Radic Biol Med 20:331-342

131. Wang J, Pantopoulos K (2005) The pathway for IRP2 degradation involving 2-oxoglutarate-dependent oxygenase(s) does not require the E3 ubiquitin ligase activity of pVHL. Biochim Biophys Acta 1743:79-85
132. Wang JZ, Grundke-Iqbal I, Iqbal K (2007) Kinases and phosphatases and tau sites involved in Alzheimer neurofibrillary degeneration. Eur J Neurosci 25:59-68

133. Weinreb O, Amit T, Youdim MB (2008) The application of proteomics for studying the neurorescue activity of the polyphenol (-)-epigallocatechin-3-gallate. Arch Biochem Biophys 476:152-160

134. Weinreb O, Amit T, Youdim MB (2007) A novel approach of proteomics and transcriptomics to study the mechanism of action of the antioxidant-iron chelator green tea polyphenol (-)-epigallocatechin-3-gallate. Free Radic Biol Med 43:546556

135. Weinreb O, Mandel S, Amit T, Youdim MB (2004) Neurological mechanisms of green tea polyphenols in Alzheimer's and Parkinson's diseases. J Nutr Biochem 15:506-516

136. Weinreb O, Mandel S, Bar-Am O, Yogev-Falach M, Avramovich-Tirosh Y, Amit T, Youdim MB (2009) Multifunctional neuroprotective derivatives of rasagiline as antiAlzheimer's disease drugs. Neurotherapeutics 6:163-174

137. Weinreb O, Mandel S, Youdim MB (2003) Gene and protein expression profiles of anti- and pro-apoptotic actions of dopamine, R-apomorphine, green tea polyphenol (-)-epigallocatechine-3-gallate, and melatonin. Ann N Y Acad Sci 993:351361

138. Weinreb O, Mandel S, Youdim MBH (2003) CDNA gene expression profile homology of antioxidants and their antiapoptotic and pro-apoptotic activities in human neuroblastoma cells. FASEB J 17:935-937

139. Weisburger JH, Chung FL (2002) Mechanisms of chronic disease causation by nutritional factors and tobacco products and their prevention by tea polyphenols. Food Chem Toxicol 40:1145-1154

140. Williams RJ, Spencer JP, Rice-Evans C (2004) Flavonoids: antioxidants or signalling molecules? Free Radic Biol Med $36: 838-849$

141. Wiseman SA, Balentine DA, Frei B (1997) Antioxidants in tea. Crit Rev Food Sci Nutr 37:705-718

142. Wu CD, Wei GX (2002) Tea as a functional food for oral health. Nutrition 18:443-444

143. Xia Z, Dickens M, Raingeaud J, Davis RJ, Greenberg ME (1995) Opposing effects of ERK and JNK-p38 MAP kinases on apoptosis. Science 270:1326-1331

144. Xu Z, Chen S, Li X, Luo G, Li L, Le W (2006) Neuroprotective effects of (-)-epigallocatechin-3-gallate in a transgenic mouse model of amyotrophic lateral sclerosis. Neurochem Res 31:1263-1269

145. Yang B, Arai K, Kusu F (2000) Determination of catechins in human urine subsequent to tea ingestion by high-performance liquid chromatography with electrochemical detection. Anal Biochem 283:77-82

146. Yang CS, Kim S, Yang GY, Lee MJ, Liao J, Chung JY, Ho CT (1999) Inhibition of carcinogenesis by tea: bioavailability of tea polyphenols and mechanisms of actions. Proc Soc Exp Biol Med 220:213-217

147. Yang F, de Villiers WJ, McClain CJ, Varilek GW (1998) Green tea polyphenols block endotoxin-induced tumor necrosis factorproduction and lethality in a murine model. J Nutr 128:23342340

148. Yonemitsu K, Koreeda A, Higuchi A, Tsunenari S (1999) Protective effects of green TEA and epigallocatechin gallate against paraquat toxicity in mice. Jpn J Toxicol 12:143-150

149. Youdim KA, Dobbie MS, Kuhnle G, Proteggente AR, Abbott NJ, Rice-Evans C (2003) Interaction between flavonoids and the blood-brain barrier: in vitro studies. J Neurochem 85:180-192

150. Zaman K, Ryu H, Hall D, O’Donovan K, Lin KI, Miller MP, Marquis JC, Baraban JM, Semenza GL, Ratan RR (1999) 
Protection from oxidative stress-induced apoptosis in cortical neuronal cultures by iron chelators is associated with enhanced DNA binding of hypoxia-inducible factor-1 and ATF-1/CREB and increased expression of glycolytic enzymes, p21(waf1/ cip1), and erythropoietin. J Neurosci 19:9821-9830

151. Zecca L, Gallorini M, Schunemann V, Trautwein AX, Gerlach M, Riederer P, Vezzoni P, Tampellini D (2001) Iron, neuromelanin and ferritin content in the substantia nigra of normal subjects at different ages: consequences for iron storage and neurodegenerative processes. J Neurochem 76:1766-1773

152. Zhang Q, Tang X, Lu Q, Zhang Z, Rao J, Le AD (2006) Green tea extract and (-)-epigallocatechin-3-gallate inhibit hypoxia- and serum-induced HIF-1alpha protein accumulation and VEGF expression in human cervical carcinoma and hepatoma cells. Mol Cancer Ther 5:1227-1238

153. Zhao B, Guo Q, Xin W (2001) Free radical scavenging by green tea polyphenols. Methods Enzymol 335:217-231

154. Zhou YD, Kim YP, Li XC, Baerson SR, Agarwal AK, Hodges TW, Ferreira D, Nagle DG (2004) Hypoxia-inducible factor-1 activation by (-)-epicatechin gallate: potential adverse effects of cancer chemoprevention with high-dose green tea extracts. J Nat Prod 67:2063-2069 